\title{
In vitro techniques of bovine oocyte maturation, fertilization and embryo culture resulting in the birth of a calf
}

\author{
A. Pavlok, J. Motlík, J. Kaňka and J. Fulka
}

The Czechoslovak Academy of Sciences, Institute of Physiology and Genetics of Farm Animals, Department of Genetics, 27721 Liběchov, Czechoslovakia

(3rd Franco-Czechoslovak Meeting, INRA, Jouy-en-Josas, 13-14 December 1988)

Summary - Oocyte cumulus complexes were aspirated from 3 to $5 \mathrm{~mm}$ follicles of cows prestimulated with 2.000 IU PMSG $24 \mathrm{~h}$ before slaughter. Oocytes matured in culture were fertilized in vitro by heparinized freshly ejaculated or epididymal spermatozoa. The cultivation procedure for fertilized eggs was the same as that used for cultivation of oocytes. From 163 matured oocytes, 109 cleaved to the 2-cell stage $24 \mathrm{~h}$ after fertilization and after 6 days of cultivation, 18 developed to the late morula and 18 to the blastocyst stages. Eleven blastocyts and 1 late morula were transferred surgically to the uteri of 7 recipient heifers. Two heifers became pregnant : one delivered a bull-calf at term, while the other pregnancy resulted in abortion at the 3rd month. The examination of some embryos by transmission electron microscopy showed an almost normal morphology for most cells. The degenerated cells contained mostly electron-dense residual bodies of unknown origin.

fertilization in vitro - development — bovine embryos

Résumé - Techniques de maturation ovocytaire, de fécondation et de culture embryonnaire in vitro permettant l'obtention d'un veau. Des ovocytes entourés de leur cumulus oophorus sont aspirés de follicules de 3 à $5 \mathrm{~mm}$ de diamètre prélevés sur des vaches traitées avec $2000 \mathrm{UI}$ de PMSG $24 \mathrm{~h}$ avant l'abattage. Les ovocytes sont cultivés jusqu'à maturation, puis fécondés in vitro avec des spermatozoïdes héparinisés juste après récolte (sperme éjaculé ou épididymaire), d'après Pavlok et al. (1988). La technique de culture in vitro des œufs fécondés est la même que celle employée pour les ovocytes. Sur 163 ovocytes maturés, 109 se segmentent une fois en $24 \mathrm{~h}$ après fécondation et, au bout de 6 jours de culture, 18 atteignent le stade morula tardive et 18 le stade blastocyste. Après transfert chirurgical intra-utérin chez 7 génisses de 11 blatocystes et une morula, deux receveuses sont gestantes. Une met bas un veau mâle à terme, l'autre avorte au $3^{\theta}$ mois. L'examen de quelques embryons au microscope électronique à transmission révèle une morphologie normale pour la plupart des cellules. Les cellules dégénérées renferment des corps résiduels opaques aux électrons.

fécondation in vitro - développement - embryon bovin 


\section{INTRODUCTION}

As described by Bavister (1988) the cleavage of cattle one-cell zygotes cultured in vitro is blocked at the 8-cell stage. However, follicular oocytes, matured and fertilized in vitro, can overcome this 8-cell block and develop to the morula or blastocyst stage, after deposition into oviducts of the same or foreign species (Boland, 1984; Sirard et al., 1985; Lu et al., 1987) or in coculture with oviductal or follicular cells (Eystone et al., 1987; Fuduka et al., 1988; Lu et al., 1988; Thibault et al., 1988).

This paper describes a simple and effective culture technique which supports the development of a high proportion of $z y-$ gotes up to the morula and blastocyst stages. The transfer in vivo of some of them was used to give us information about the viability of such embryos. A short communication on the results obtained has recently been presented in Czech (Pavlok et al., 1988a).

\section{MATERIALS AND METHODS}

Oocyte cumulus complexes were aspirated from 3-5 mm diameter follicles of slaughtered cows stimulated $24 \mathrm{~h}$ previously with $2000 \mathrm{IU}$ PMSG. Before treatment with PMSG, animals were preselected according to the presence of welldeveloped corpora lutea.

Modified Parker's medium (M 199; SevacPraha) supplemented with $2.92 \mathrm{mmol} / \mathrm{Ca}$ lactate, $2 \mathrm{mmol} / \mathrm{l} \mathrm{Na}$-pyruvate, $33.9 \mathrm{mmol} / \mathrm{l} \mathrm{Na}$ bicarbonate, $4.43 \mathrm{mmol} / \mathrm{l}$ Hepes buffer, $50 \mathrm{IU} / \mathrm{ml}$ penicillin, $50 \mu \mathrm{l} / \mathrm{ml}$ streptomycin sulphate and $20 \%$ of bovine inactivated serum (BOS; SevacPraha) designated as "MPM 20" was used for culture of oocyte cumulus complexes. This culture medium $(150 \mu l)$ was placed in a watchglass under paraffin oil and equilibrated at a temperature of $38.5^{\circ} \mathrm{C}$ in $4 \% \mathrm{CO}_{2}, 10 \% \mathrm{O}_{2}$ and $86 \% \mathrm{~N}_{2}$ for at least $2 \mathrm{~h}$. The culture of oocytes $\approx$ 20-30 per watch-glass was carried out for 24-26 h.

Four hundred $\mu \mathrm{l}$ of ejaculated semen of good sperm motility were diluted with MPM + $10 \%$ BOS ("MPM 10") $1-3 \mathrm{~h}$ after collection and centrifuged at $\approx 700 \mathrm{~g}$ in $4 \mathrm{ml}$ tubes for 10 min. After discarding the supernatant, this procedure was repeated once with MPM 10 and once with $100 \mathrm{IU} / \mathrm{ml}$ of heparin in KrebsRinger phosphate. The appropriate portion of the centrifuged heparin-treated spermatozoa was resuspended in $1 \mathrm{ml}$ of MPM 10 to a concentration of approximately $1.0-2.0 \times 10^{8} / \mathrm{ml}$ and incubated for $40-60 \mathrm{~min}$ at $38.5^{\circ} \mathrm{C}$. To obtain the epididymal spermatozoa, the ducti deferentes with adjacent distal caudae epididymis were dissected and spermatozoa flushed with 2 $\mathrm{ml}$ of MPM 10, stored at room temperature for $\approx$ $20 \mathrm{~h}$. Of these spermatozoa $200-300 \mu \mathrm{l}$ aliquots were treated as freshly collected ejaculates.

At the end of culture, the oocytes with expanded cumuli were transferred into $4-5 \mathrm{ml}$ of MPM 10 and mixed with the upper layer of the nonsedimented part of preincubated spermatozoa to give a final concentration of $1.0-2.0 \times$ $10^{6} \mathrm{spermatozoa} / \mathrm{ml}$. For fertilization and subsequent culture gametes and zygotes were maintained at the same temperature and atmosphere as the cultured oocytes. Twenty to 24-hold zygotes together with the remains of adherent follicular cells were transferred into $150 \mu \mathrm{l}$ of MPM 20 and cultured in the same manner as the oocytes. This medium was changed only once (after $\approx 90 \mathrm{~h}$ ) during the whole culture period. At the same time, the evidently degenerated or retarded embryos were removed from the culture, together with the remains of follicular cells surrounding all embryos. The healthylooking embryos without follicular cells were cultured $1-2$ days more (see Table I).

Seven recipient heifers were synchronized with $500 \mu \mathrm{g}$ of cloprostenol (Oestrophan- Spofa) injected during the luteal phase of their cycle to induce estrus at the day of the start of donor oocytes cultivation. Nine 7-day, two 6-day blastocysts and one 6-day morula from all 4 experiments were surgically transferred to the uteri of synchronized recipients (Table I).

Embryos not used for transfer were fixed in acetic acid-ethanol $(1: 3)$ for $24 \mathrm{~h}$, stained 


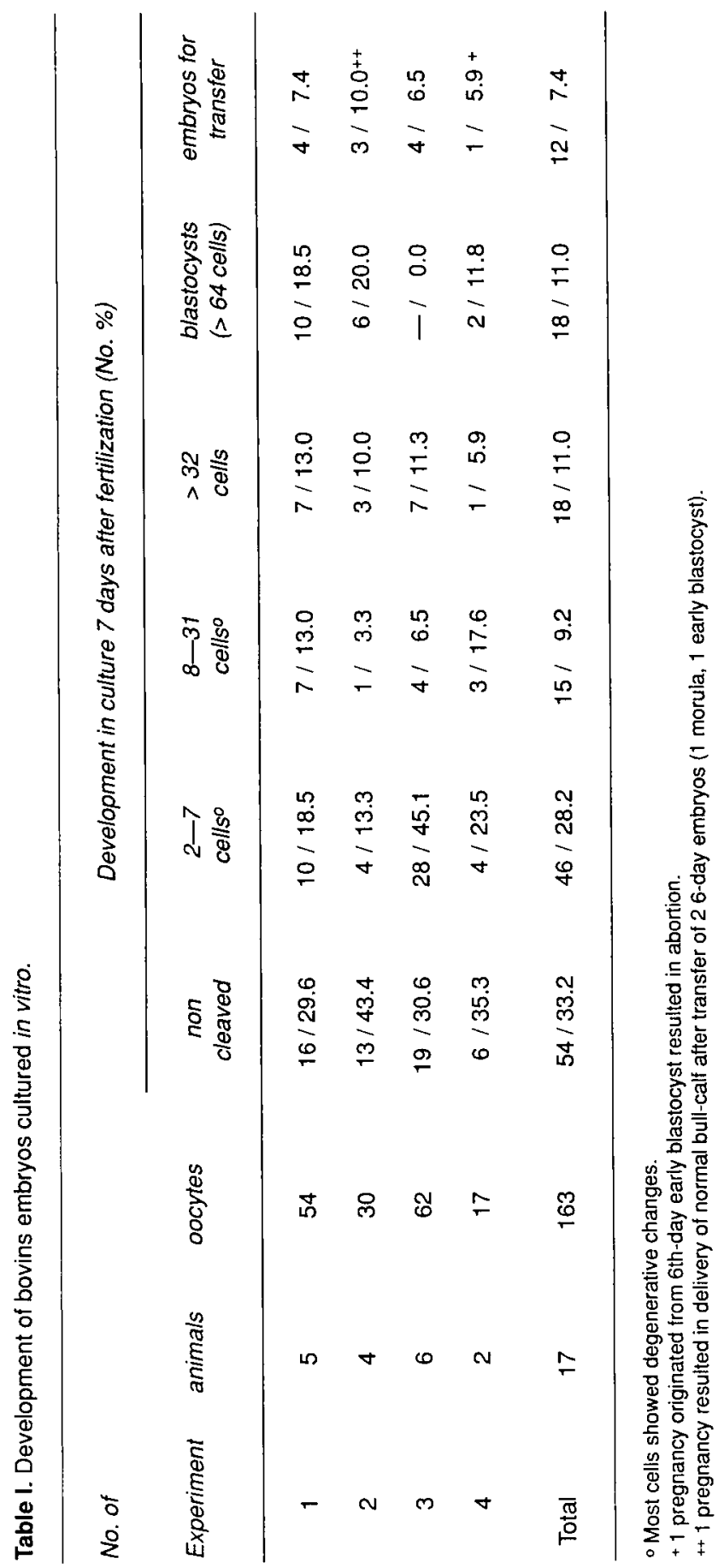


with $1 \%$ acetic orcein, differentiated in $30-50 \%$ acetic acid and evaluated by phase contrast microscopy. Attention was paid to the number of cells of each embryo.

In addition, 4 blastocysts were fixed, stained and sectioned for electron microscopy as described earlier (Fléchon and Pavlok, 1986). UItrathin sections were examinated with a Jeol 1200 EX electron microscope. erative changes. In contrast, the electrondense residual bodies were found in about a quarter or more of embryoblast cells of two retarded blastocysts (darker under the stereomicroscope and with a smaller irregular blastocell cavity).

\section{DISCUSSION}

\section{RESULTS}

From 163 cultured and inseminated oocytes, 109 cleaved to the 2-cell stage $\approx$ $24 \mathrm{~h}$ after sperm-egg mixing. During the subsequent 6 days of in vitro cultivation, 18 embryos developed to the morula stage (> 32 cells) and 18 to the blastocyst stage (> 64 cells) (Table I, Fig. 1). Many blastocysts started to expand (Fig. 2).

The transfer of 11 blastocysts and 1 morula to the uteri of 7 recipients resulted in two pregnancies. One healthy bull-calf (from experiment 2, Table 1) was born at term; however, the second pregnancy (from experiment 4, Table I) resulted in abortion at the 3rd month.

The observation of blastocysts in TEM showed that in healthy-looking blastocysts most of the cells were morphologically normal but contained a large amount of lipid material (Fig. 3). In well-developed blastocysts, only 1 or 2 cells per a middle embryoblast section contained electrondense residual bodies as a sign of degen-

When bovine embryos were cocultured with a monolayer of oviductal cells (Eystone et al., 1987; Lu et al., 1988; Fukui and Ono, 1988; Thibault, 1988), or with granulosa cells (Fukuda et al., 1988), the 8-cell cleavage block (Bavister, 1988) was somehow suppressed and some embryos were able to develop to the morula or blastocyst stage.

The authors cited above used mainly $M$ 199 or Ham F 10 media, buffered either with $\mathrm{Na}$-bicarbonate or Hepes and supplemented with fetal calf serum or cestrus cow serum. In our experiments the development of zygotes was also secured with M 199 and bovine serum, but in addition with increased amount of Na-pyruvate and with a combination of two buffer systems. In the absence of added cells, the development of embryos was probably supported by adherent corona radiata cells which surrounded practically all successfully developing embryos. As described earlier, these cells were easily removed mechanically $90 \mathrm{~h}$ later.

Figs. 1-3. Day 7 blastocysts after in vitro fertilization and cultivation observed by phase-contrast light microscopy (Figs. 1,2) and transmission electron microscopy (Fig. 3). 1, Early (a) and well-developed (b) blastocysts mounted in toto, fixed in acetic alcohol and stained with aceto-orcein. $(=x 340)$. 2, Expanded blastocyst (slightly collapsed during mounting on the slide) fixed and stained as those in Fig. 1. $(\approx x 340)$. 3, Section through the trophoblast $(T)$ and the embryoblast $(E)$ of day 7 blastocyst. Most of the cells appear normal, although containing large amount of lipids (L) and sometimes dense bodies (D). 

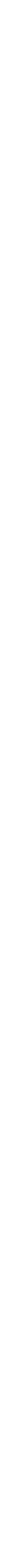
The ultrastructural study of in vitro developed blastocysts revealed healthy or degenerated cells as in blastocysts developed in vivo (Pivko et al., 1986). However, we noted a very high density of lipid inclusions in the cells of blastocysts developed in vitro. This observation could correlate with a frequent lower transparency of practically all in vitro cultivated embryos under the stereomicroscope. The study of ultrastructure in connection with synthetic activities of single cells is in progress.

Even if the present technique for culture of bovine embryos seems to be superior to culture methods described by the authors cited above and also apparently to the culture in sheep oviduct (Sirard et al., 1988), more effort is still necessary to obtain normal blastocysts under well-defined in vitro conditions and further research is required to understand the regulatory mechanisms of early embryonic development.

\section{ACKNOWLEDGMENTS}

The authors wish to thank $\mathrm{Dr}$ J.-E. Fléchon for reading the manuscript and translation of summary into French, Dr. R.H.F. Hunter for editing the text, Mrs J. Zelenková, Mr. V. Pech. and Mrs. J. Schwarzová for technical help.

\section{REFERENCES}

Bavister B.D. (1988) Role of oviductal secretions in embryonic growth in vivo and in vitro. Theriogenology 29, 143-154

Boland M.P. (1984) Use of the rabbit oviduct as a screening tool for the viability of mammalian eggs. Theriogenology 21, 126 (abstr.)
Eystone W.H., Vignieri J. \& First N.L. (1987) Co-culture of early bovine embryos with oviductal epithelium. Theriogenology 27, 228 (abstr.)

Fléchon J.E. \& Pavlok A. (1986) Ultrastructural study of the interactions and fusion of ram spermatozoa with zona-free hamster oocytes. $R e$ prod. Nutr. Develop. 26, 999-1008

Fukuda Y., Ichikava M., Naito K. \& Toyoda Y. (1988) Normal development of bovine oocytes matured, fertilized and cultured with cumulus cells in vitro. 11th Int. Congr. Anim. Reprod. Artif. Insem., Dublin, p. 327

Fukui Y. \& Ohno H. (1988) In vitro development to blastocyst of in vitro matured and fertilized bovine oocytes. Vet. Rec. 122, 282 (abstr.)

Lu K.H., Gordon I., Gallagher M. \& Mc Govern $H$. (1987) Pregnancy established in cattle by transfer of embryos derived from in vitro fertilization of oocytes matured in vitro. Vet. Rec. $121,259-260$

Lu K.H., Gordon I., Chen H.B., Gallagher M. \& Mc Govern H. (1988) Birth of the twins after transfer of cattle embryos produced by in vitro techniques. Vet. Rec. 122, 539 (abstr.)

Pavlok A., Kaňka J., Motlík J. \& Fulka J. (1988a) Oplozeni in vitro a preimplantačni vy̌voj u skotu. XIV. dny fyziologie hospodářsky̌ch zvirat, Liblice (in press)

Pavlok A., Torner H., Motlík J., Fulka J., Kauffold P. \& Duschinski U. (1988b) Fertilization of bovine oocytes in vitro: effect of different sources of gameles on fertilization rate and frequency of fertilization anomalies. Anim. Reprod. Sci. 16, 207-213

Pivko J., Kopečný V., Tománek M., Kaňka J. \& Fléchon J.E. (1986) Autoradiography of $3 \mathrm{H}$ uridine incorporation in the normal early blastocysts of cattle. Reprod. Nutr. Develop. 26, 10091085

Sirard M.A., Lambert R.D., Ménard D.P. \& Bedoya M. (1985) Pregnancies after in vitro fertilization of cow follicular oocytes, their incubation in rabbit oviduct and their transfer to the cow uterus. J. Reprod. Fertil. 75, 551-556

Sirard M.A., Parrish J.J., Ware C.B., LeibfriedRutledge M.L. \& First N.L. (1988) The culture of bovine oocytes to obtain developmentally competent embryos. Biol. Reprod. 39, 546-552

Thibault C., Marquant-Le Guienne B. \& Gérard M. (1988) In vitro development of in vivo and in vitro fertilized bovine eggs on tubal and uterine cell monolayers. J. Reprod. Fertil.. 2, 24 (abstr.) 